\title{
What should doctors and healthcare staff do when industrial action jeopardises the lives and health of patients?
}

\author{
D J McQuoid-Mason, BComm, LLB, LLM, PhD \\ Centre for Socio-Legal Studies, University of KwaZulu-Natal, Durban, South Africa
}

Corresponding author: D J McQuoid-Mason (mcquoidm@ukzn.ac.za)

\begin{abstract}
During the recent strikes by healthcare personnel in North West Province, South Africa, patients were prevented from accessing emergency medical care and doctors and nurses were ejected from hospitals. Such conduct violates the Constitution of the Republic of South Africa, 1996, and is unlawful, as health services are 'essential services' in terms of the Labour Relations Act No. 66 of 1995. Doctors, nurses and other healthcare personnel who are prevented from assisting patients by striking colleagues should take active steps to secure access to healthcare services for patients requiring emergency medical care.
\end{abstract}

S Afr Med J 2018;108(8):634-635. DOI:10.7196/SAMJ.2018.v108i8.13479

About 64 patients in one district may have died because striking healthcare personnel in North West Province, South Africa (SA) prevented them from accessing medical treatment. ${ }^{[1]}$ Thousands more 'may have suffered permanent damage after not being able to get their medicines from public health pharmacies - including antiretroviral medication and medicine for mental illnesses. ${ }^{[1]}$ Strikers also chased doctors and nurses out of operating theatres and wards. ${ }^{[1]}$

\section{Is the right to strike absolute?}

Everyone has the right to strike (the Constitution of the Republic of SA, 1996, ${ }^{[2]}$ section 23(2)), but such right is not absolute. For instance, strike action may not violate other constitutional rights, such as the right to life (section 11), right of access to healthcare (section 27(1)), right not to be refused emergency medical treatment (section 27(3)) and right of children to basic healthcare services (section 28(1)). The Constitution provides that rights may be limited where this is reasonable and justifiable in a democratic society based on human rights, equality and freedom. Such limitations apply to the right to strike by 'essential service' providers under the Labour Relations Act No. 66 of 1995. ${ }^{[3]}$ In this regard, the courts must take into account all relevant factors, including: (i) the nature of the right (i.e. the right to strike); (ii) the importance of the purpose of the limitation (e.g. to save patients from suffering serious harm or death); (iii) the nature and extent of the limitation (e.g. it is limited with regard to 'essential services'); and (iv) the relation between the limitation and its purpose (e.g. the limitation ensures that seriously ill or injured patients receive medical attention during a strike) (section 36(1)).

When applying the limitation clause the court must determine that the limitation is not disproportionate to its purpose. ${ }^{[4]}$ In other words, is there a less restrictive way to ensure that such patients are protected without imposing a blanket prohibition against striking or other industrial action by essential service employees (i.e. could a strike be allowed without endangering patients who are seriously ill or in danger of dying?).

\section{Are healthcare personnel 'essential'} service providers who may not strike? The Labour Relations Act $^{[3]}$ regards certain services as essential services, whose providers may not strike unless particular conditions are fulfilled (section 65). Such essential services include 'a service, the interruption of which endangers the life, personal safety or health of the whole or any part of the population' (section 213). In the public healthcare sector, the declaration of essential services is to ensure that seriously ill or injured patients receive emergency medical attention during a strike.

The Labour Relations $\mathrm{Act}^{[3]}$ allows for the establishment of an essential services committee (ESC) under the Commission for Conciliation, Mediation and Arbitration (CCMA) (section 70). The ESC must investigate whether a particular service should be declared an essential service and whether it should remain as an essential service. It may also ratify any collective agreement that provides for 'minimum services' in an essential service. It has been suggested that the SA government has deliberately avoided finalising a minimum service agreement in the public health sector so that the ESC can impose a blanket ban on industrial action by state-employed healthcare employees. ${ }^{[5]}$ However, such a blanket ban on industrial action by public health-sector employees may be unconstitutional because the state has not used the least restrictive means of minimum service agreements. ${ }^{[6]}$

Given the ongoing unrest in the public health sector, the unions and government should urgently negotiate a minimum service agreement to ensure that during strikes the health and lives of patients are protected by the employment of skeleton staff. ${ }^{[1]}$

\section{Legal and ethicall rules regarding} strike action by health personnel

Under the Labour Relations Act ${ }^{[3]}$ the ESC has designated emergency health services, nursing, medical and paramedical services, their supporting services and hospitals, as essential services. ${ }^{[5]}$ The declaration of essential services is to ensure that seriously ill or injured patients are not refused emergency medical attention during 
a strike. Essential service providers may not prevent patients from accessing healthcare, or prevent seriously ill or injured persons from receiving emergency medical treatment. Patients harmed by essential service providers preventing them from accessing healthcare may sue them civilly, and lay criminal charges if they assault or allow such patients to die through their acts or omissions. The same applies to health authorities that do not take steps to maintain services for patients requiring emergency medical treatment. ${ }^{[7]}$

It is unconstitutional, unlawful and unethical for essential service employees to obstruct access to healthcare for seriously ill patients or prevent patients from receiving emergency medical treatment. Apart from the legal implications, striking healthcare personnel are not exempt from the ethical rules governing their profession in situations where patients are seriously ill or injured. The bioethical principles of autonomy, beneficence, non-maleficence and justice apply to healthcare workers in essential services during a strike. ${ }^{[8]}$

\section{What should doctors and healthcare staff do when picketing strikers prevent them from entering hospital premises?}

Everyone 'has the right, peacefully and unarmed, to assemble, to demonstrate, to picket and to present petitions' (the Constitution, ${ }^{[2]}$ section 17). The Labour Relations Act $^{[3]}$ states that members and supporters of registered trade unions may picket 'for the purposes of peacefully demonstrating' (section 69(1)). Thus, workers involved in picketing may not use violence to prevent doctors and healthcare personnel from entering hospitals during a strike and may not eject them from hospitals. The use of violence to prevent doctors and other healthcare personnel from attending to patients is unconstitutional and illegal, and the police must prevent this by upholding the Constitution and enforcing the law. ${ }^{[9]}$

If non-striking doctors, nurses and healthcare personnel try to assist patients who require emergency treatment in a hospital during strike action, and are prevented from doing so by picketing, they should:

- Approach the hospital authorities to secure police protection to enable them to attend to emergency medical cases in the hospital. Their request, in writing, should be handed to the relevant hospital official (keeping a copy for themselves) and, if necessary, remind hospital administrators that hospitals, as essential service providers, have a legal and ethical duty to make emergency medical services available.

- Approach the nearest police station to provide them with safe passage through the pickets and, if necessary, protection in the hospital to allow them to administer to patients, if the hospital authorities fail to act within a reasonable period (within 1 hour).

- Remind the police about the provisions in the Constitution and the National Health Act No. 61 of $2003^{[10]}$ concerning emergency medical treatment if they decline to assist. The station commissioner should be advised that he or she would be personally responsible should any patients suffer further complications or die because healthcare personnel could not cross the picket line to assist patients requiring emergency medical treatment. They should confirm their request and warning to the station commissioner in writing and hand a copy to him or her - keeping a copy for themselves.

- Bring an urgent high court application in the public interest to seek an order from the court compelling the hospital authorities and police to provide the necessary protection if the hospital authorities and police fail to assist them. Such an order to the duty judge may be at any time of the day, including weekends. The court is likely to grant an order if it can be demonstrated that the unlawful forms of picketing and inaction by the hospital authorities and the police are jeopardising the health and lives of patients. As they are acting in the public interest, such assistance may be obtained from an organisation such as the Legal Resources Centre, and a court would not award costs against them in the unlikely event that it does not grant an order. ${ }^{[11]}$

Acknowledgements. None.

Author contributions. Sole author.

Funding. National Research Foundation.

Conflicts of interest. None.

1. Cullinan K. How to stop strikes from killing patients. Health-e News, 18 May 2018. https://www. dailymaverick.co.za/article/2018-05-20-health-e-news-how-to-stop-strikes-from-killing-patients/\#. Wx5T3UiFOUk (accessed 12 June 2018).

2. Constitution of the Republic of South Africa, 1996

3. South Africa. Labour Relations Act No. 66 of 1995 .

4. Sv Makwanyane 1995 (3) SA 391 (CC).

5. Brand J. Strikes in essential services. Accountability Now, 22 September 2010. https://accountabilitynow.

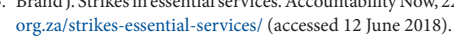

6. South African Police Service v Police and Prisons Civil Rights Union (2011) ZACC 21. http:// 6. South African Police Service v Police and Prisons Civil Rights Union (2011) ZACC 21. http://
section27.org.za/wp-content/uploads/2011/10/PATIENT-AND-HEALTH-CARE-WORKERsection27.org.za/wp-content/uploads/2011/10/PATIENT-AND-HEALTH-CARE-WORKER-
RIGHTS-ETHICS-AND-A-MINIMUM-SERVICE-LEVEL-AGREEMENT-OR-ALTERNATIVERIGHTS-ETHICS-AND-A-MINIMUM-SE
MECHANISM.pdf (accessed 12 June 2018).

7. McQuoid-Mason DJ. Public health officials and MECs should be held liable for harm caused to patients through incompetence, indifference, maladministration or negligence regarding the availability of hospital equipment. S Afr Med J 2016;106(7):681-683. https://doi.org/10.7196/samj.2016.v106i7.10722 8. Beauchamp TL, Childress JF. Principles of Biomedical Ethics. 3rd ed. Oxford: Oxford University Press, 1994. 9. Carmichele v Minister of Safety and Security 2001 (4) SA 938 (CC).

10. South Africa. National Health Act No. 61 of 2003.

11. Biowatch Trust v Registrar Genetic Resources and Others 2009 (6) SA 232 (CC). 